\title{
Neuronal intranuclear inclusion disease
}

INSERM

\section{Source}

INSERM. (1999). Orphanet: an online rare disease and orphan drug data base. Neuronal intranuclear inclusion disease. ORPHA:2289

Neuronal intranuclear inclusion disease (NIID) is a very rare multisystem

neurodegenerative disorder characterized by the presence of eosinophilic intranuclear inclusions in neuronal and glial cells, and neuronal loss. 